\title{
An update and reassessment of vascular plant species richness and distribution in Bach Ma National Park, Central vietnam
}

\author{
Cập nhật và đánh giá sự phong phú và phân bố của các loài thực vật bậc cao tại Vườn Quốc Gia \\ Bạch Mã, Việt Nam
}

\begin{abstract}
LE, Nguyen Thoi Trung1; NGUYEN, Hoang Khanh Linh²; NGUYEN, Quang Tan 2,4*; DO, Trung Dong2; PHAM, Gia Tung²; LE, Thanh An³ ; NGUYEN, Vu Bao Chi

${ }^{1}$ Museum of Nature in the Central Coast, Department of Science and Technology of Thua Thien Hue province, Vietnam; ' International School, Hue University, Hue City, Vietnam; ${ }^{3}$ University of Economics, Hue University, 99 Ho Dac Di, Hue City, Vietnam; ${ }^{4}$ Graduate School of Environmental and Life Science, Okayama University, Japan.
\end{abstract}

\begin{abstract}
Bach Ma National Park (BMNP) is recognized as an essential biodiversity hotspot in Vietnam because of its diverse topography, high species richness and threatened and endemic species. This study updates the richness and distribution of vascular plant species in the BMNP by intergrading data from literature, field surveys, key-informant interviews and participatory observations. Our results showed that the park has a high diversity of vascular plants with 1,874 species belonging to 192 families, 6 phylums including Psilotophyta, Lycopodiophyta, Equisetophyta, Polypodiophyta, Pinophyta, and Magnoliophyta. It also indicates that 199 out of 1,874 vascular species in the BMNP are listed as endangered, precious and rare plant species of Vietnam. In particular, 55 species are part of the IUCN 2020 list, in which 9 are critically endangered species (CR), 15 are endangered species (EN), and 31 are vulnerable species (VU). According to the rankings of the Red List Vietnam (2007), 6 species of CR (accounting for 13.64\% compared with the whole country), 36 species of EN (20\%), and 52 species of VU (26\%) were found in this area. The results provided that vascular plant species are distributed into 2 types based on high altitude (threshold at $900 \mathrm{~m}$ ), but there are no dominant communities. The findings may be essential information for foresters and biologists to recognize and use it as the newest update for their next scientific research in conservation and resource management.
\end{abstract}

Vườn Quốc gia (VQG) Bạch Mã được xem là một điểm nóng đa dạng sinh học quan trọng ở Việt Nam vì địa hình đa dạng, độ phong phú loài cao, đặc biệt là các loài đặc hữu và nguy cấp. Trong nghiên cứu này, chúng tôi đã cập nhật sự phong phú và phân bố của các loài thực vật bậc cao tại VQG Bạch Mã bằng cách kết hợp dữ liệu từ tổng quan tài liệu, khảo sát thực địa, phỏng vấn người am hiểu và điều tra có sự tham gia. Kết quả cho thấy VQG có hệ thực vật bộc cao phong phú với 1.874 loài, thuộc 192 họ, 6 ngành bao gồm Psilotophyta, Lycopodiophyta, Equisetophyta, Polypodiophyta, Pinophyta, Magnoliophyta. Kết quả chỉ ra rằng 199 trong số 1.874 loài thực vật bậc cao tại VQG này được xếp vào danh sách các loài nguy cấp của Việt Nam. Đặc biệt, có 55 loài thuộc danh muc của IUCN năm 2020, trong đó có 9 loài Cực kỳ nguy cấp (CR), 15 loài Nguy cấp (EN) và 31 loài Sẽ nguy cấp (VU). Trong khi đó, theo xếp hạng của Sách Đỏ Việt Nam (2007), nghiên cứu cho thấy có 6 loài CR (chiếm 13,64\% so với cả nước), 36 loài EN (20\%) và 52 loài VU (26\%). Phát hiện của chúng tôi cũng chỉ ra rằng đặc điểm phân bố của các loài thực vật bậc cao ở VQG Bạch Mã gồm 2 kiểu rừng dựa trên độ cao (mức 900m), nhưng không có quần xã nào chiếm ưu thế. Các kết quả này được kỳ vọng sẽ là nguồn thông tin cần thiết cho các nhà hoạt động lâm nghiệp và sinh vật học sử dung nó như một bản cập nhật mới nhất cho các nghiên cứu khoa học tiếp theo trong bảo tồn và quản lý tài nguyên.

Keywords: Bach Ma National Park, vascular plants, the Red List Vietnam, the richness and distribution

\section{Introduction}

Currently, biodiversity loss is one of the most critical threats to global environments, especial in "hot spot" areas (Nakano,
Yahara, \& Nakashizuka, 2012). To halt this biodiversity loss, many efforts at the global, regional, and national levels have been made since the world's governments' agreement in 2002. The establishment of national parks (NPs) is one of the
* Corresponding author

Email : nguyenquangtan@hueuni.edu.vn
http://dx.doi.org/10.13141/JVE ISSN 2193-6471 
significant initiatives, that have been adopted by many countries, making an essential contribution to those efforts. The NPs are recognized as the most crucial core units for in situ conservation (An et al., 2018), being important for a functional ecosystem, for conservation and protection of the natural environment (Bruner et al., 2001). Vietnam is no an exception. The first NP in Vietnam was established in 1966; currently, there are 31 NPs in the whole country which are managed by the Forestry Administration under the Ministry of Agriculture and Rural Development (MARD) (Iwanaga et al., 2019).

Besides richness on species, the NPs can notably differ in terms of species composition. Studies of differences between compositional dissimilarity can inform the prioritization of the NPs and the management of biological invasions (Fois et al., 2020). According to Nakano et al. (2012), science in the NPs is expected to play a leading role in the area of biodiversity, including the characterization of the biodiversity of various areas, clarifying ecosystem services, quantifying how rapidly biodiversity is being lost, justifying needs and identifying possibilities for conservation and a sustainable use of the biodiversity (Nakano et al., 2012).

Located in Central Vietnam, Bach Ma national park (BMNP) was officially established in 1991 with an area of 22,031 ha; it currently has 37,487 ha as expended policy in 2018 (Iwanaga et al., 2019). This park is one of the highest priority biodiversity conservation areas in Vietnam; more specifically, the park is home to a diverse range of species, including 2,373 species of fungi and flora and 2,151 species of fauna (BMNP, 2020). In the context of national plant diversity, the BMNP represents the important areas in Central Vietnam due to their exceptional number of endangered and endemic plants. However, the park faces various threats to its biodiversity conservation activities and natural resource management, including the illegal wildlife trade, illegal hunting and lack of funds for biodiversity conservation (An et al., 2018).

Despite constant research (Quang et al., 2007; Phu, 1999), most of it focus on the park's former area. On the other hand, due to negative human impacts on the BMNP extended region, factors affecting the biodiversity and habitat are discovered, such as illegal activities and ecosystem degradation due to various activities of the community (Dan et al., 2014). Species names and the classification system of vascular plant species have changed year by year. Therefore, it is necessary to have investigations to discover new species to supplement or update the list of vascular plant species in the park for research and conservation activities. This study aims (1) to estimate the biodiversity of vascular plant species based on the results of field survey, (2) to compare with the list found by former authors, and (3) to provide further data on the current status of biological resources, mainly vascular plant species (VPS) in the BMNP.

\section{Materials and methods}

\subsection{Study site}

This research was conducted in the BMNP, located in the central part of Vietnam between $15^{\circ} 59^{\prime} 28^{\prime \prime}$ to $16^{\circ} 16^{\prime} 02^{\prime \prime}$ North and $107^{\circ} 37^{\prime} 22^{\prime \prime}$ to $107^{\circ} 54^{\prime} 58^{\prime \prime}$ East (Fig. 1). The BMNP was selected as the study site because of its important location, unique landscape, diverse ecosystem and policy changes. Specially, this area is considered as one of the NPs with high biodiversity. Concurrently, due to its location in a transition region between North and South sites, the park plays an important role in the tropical forest ecosystems and biodiversity.

The BMNP is formed by high mountains, being the highest point the Bach Ma peak, up to 1,444 m above the sea level. Notably, since the national park establishment in 1991, the BMNP has issued to expand the park area from 21,030 ha to 37,487 ha. Since then, there have been little research, in both, the previous and the newly expanded forest area of the park, especially the VPS. This expansion of the park brought the park closer to human residences (approximately 79,000 people live in the buffer zone), increasing the park's sensitivity to social impact (Iwanaga et al., 2019). In the buffer zone surrounding the park, there are four ethnic groups: Kinh, Ka Tu, Van Kieu, and Muong, accounting for about 19\% of the population. Farming practices are mainly rice and livestock, forest planting and exploitation, etc. In Phu Loc, Loc Dien, or Khe Tre towns, apart from agriculture and forestry production, people could also get commercial and services income. This part of the buffer zone covers 58,676 hectares and spreads over the provinces of Thua Thien Hue and Quang Nam; these provinces include three districts: Phu Loc, Nam Dong and Dong Giang with 15 communes and towns and 109 villages. There are still several poor and sub-poor households, living mainly based on forest resources such as wildife hunting and illegal exploitation of forest products.

The BMNP is located in the Centre of Truong Son, the general characteristic of the enlarged area of Bach $\mathrm{Ma}$ is primarily separated. The mountainside's width is narrow, so the mountainside is very sloping, the medium angle of the area is from $15^{\circ}-35^{\circ}$. Many places have a slope of over $45^{\circ}$ so it causes trouble to move. The Park is located in the tropical monsoon. The average annual temperature of the whole region is $25^{\circ} \mathrm{C}$ but above $1.200 \mathrm{~m}$, the average annual temperature is about $19^{\circ} \mathrm{C}$. The humidity is high at the Bach Ma summit, accounting for $90 \%$. The average humidity is $85 \%$ for the whole region. The annual rainfall is about $3,500 \mathrm{~mm}$ and it can vary from region to region. 


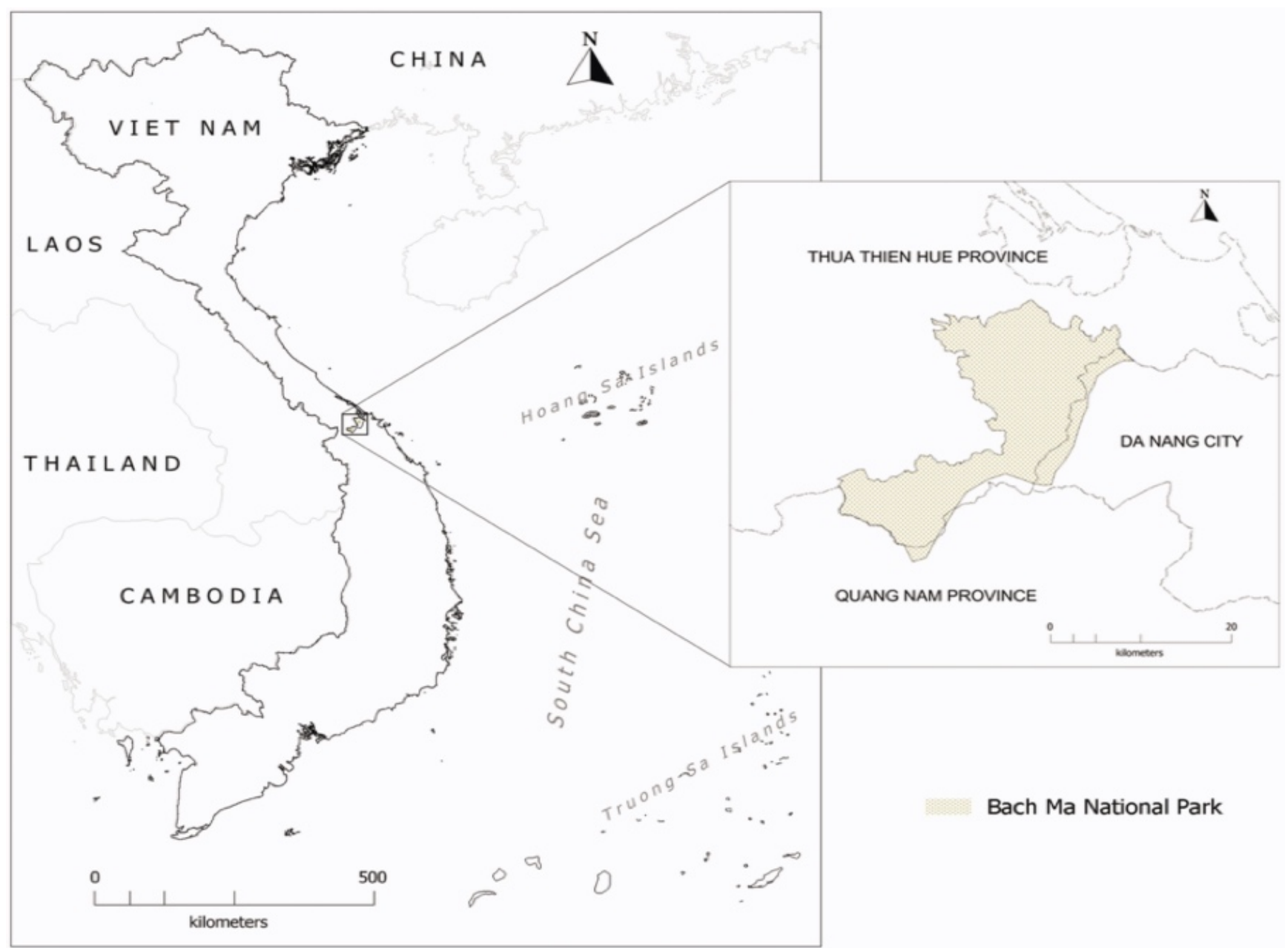

Figure 1. Location of Bach Ma National Park, Thua Thien Hue Province, Vietnam

The annual rainfall is about $8,000 \mathrm{~mm} /$ year at the Bach $\mathrm{Ma}$ summit area. The rain starts from September to December accounting for over $70 \%$ of the total annual rainfall. The park has a watershed function of water conditioning for the major rivers in the region such as the Truoi river, Cu De river, and Ta Trach river (upstream of the Perfume river). With such complex topography, it is not surprising that this area is home to 1,715 species of fauna ( $7 \%$ of the total number of species in the country) and 2,373 species of flora and mushrooms, which accounts for nearly $17 \%$ of the total number of flora species in the country (BMNP, 2020).

\subsection{Methods}

This study applied a mix of several methods, including literature review, household surveys, key-informant interviews and participatory observations.

Reviewing the literature: data was collected, analyzed from previous studies on the VPS in the BMNP from both, published and unpublished sources. The research focused mainly on the monograph "Flora in Bach Ma National Park" edited by Keo et al. (2016). Meanwhile, a list of plant species was analyzed according to Ho's inspection documents and classification course (Ho, 1991; 1992; 1993) and Thin (Thin,2004).

Field surveys and data collection: The data was obtained using a mix of two methods namely line transect and standard cell. First, four survey lines were drawn to meet the objectives, as follows:

+ Line 1: from the mountain's foot to the top

+ Line 2: along the Truoi lake

+ Line 3: along the Mo waterfall

+ Line: along the hydroelectric plant

The species touching the lines were recorded according the characteristics of vegetation types, statistic of the species and human impacts along the line's whole length (with a wide of $20 \mathrm{~m}$ ). Second, three standard cells with a size of $1,000 \mathrm{~m}^{2}$ $(50 \mathrm{~m} \times 20 \mathrm{~m})$ were established to measure and record on each line. At the same time, at the 4 corners of each cell, 4 standard plots with an area of $100 \mathrm{~m}^{2}(10 \mathrm{~m} \times 10 \mathrm{~m})$ were 
designated to record small trees, shrubs, and lianas. Simultaneously, field surveys were carried out by interviewing villagers living in the buffer zones, woodmen, and forest rangers from May to August of 2019.

This method gives essential information about the presence of the VPS. Interviewing local people revealed the remaining plants' relics in people's houses and plants for ornamental purposes, medicinal herbs, and medical treatment. This method helped to assess resource exploitation and biodiversity conservation. At the same time, plant species are recorded to form the lists. Only collect standards of species qualified for the specimen samples, species names are unknown, species have economic and science value. By contrast, plant species, not identified in the field, were fixed with newsprint and sample storage clips. Samples were transported to the laboratory for further identification.

Key-informant interviews: The study was organized with focus groups discussions with key-informant who are experts, foresters, and scientists in the research fields. Leading questions were given in that discussions focused on their perspectives in policy, resource management and biodiversity. At the same time, cross-checking collected information was discussed.

\section{Results and discussion}

\subsection{Vascular plant species composition}

The BMNP is one of the highest priority biodiversity conservation areas in Vietnam. Since the park's establishment, many researchers have discovered new species and added them to the list of biodiversity within BMNP. As displayed in Table 1, data indicates that the BMNP is known as a home to a highly diverse VPS comprising 1,874 species, belonging to 192 families, and 6 phylums including Psilotophyta (1 family and 1 species); Lycopodiophyta (2 families and 17 species); Equisetophyta (1 family and 1 species); Polypodiophyta (24 families and 170 species); Pinophyta (7 families and 22 species); and Mangnoliophyta (157 families and 1,663 species).

Table 1. The composition of vascular plant species in Bach Ma National Park

\begin{tabular}{|c|c|c|c|c|c|}
\hline & \multirow[t]{2}{*}{ Phylums } & \multicolumn{2}{|l|}{ Families } & \multicolumn{2}{|l|}{ Species } \\
\hline & & Number & $\%$ & Number & $\%$ \\
\hline 1 & Psilotophyta & 1 & 0.52 & 1 & 0.05 \\
\hline 2 & Lycopodiophyta & 2 & 1.04 & 17 & 0.90 \\
\hline 3 & Equisetophyta & 1 & 0.52 & 1 & 0.05 \\
\hline 4 & Polypodiophyta & 24 & 12.50 & 170 & 9.07 \\
\hline 5 & Pinophyta & 7 & 3.65 & 22 & 1.17 \\
\hline 6 & Mangnoliophyta & 157 & 81.77 & 1,663 & 88.76 \\
\hline \multicolumn{2}{|c|}{ Total } & 192 & 100 & 1,874 & 100 \\
\hline
\end{tabular}

A survey of the VPS in the BMNP by Dai and Huong (2009) found 379 species and 108 families. Compared with this result, a total of 1,495 new species and 84 new families are updated. Similarly, a recent study by Keo et al. (2016) indicated that 168 families and 1,816 species were found in this park. Therefore, our results provided 24 more families and 58 species. Obviously, this research has discovered several new species and families that will be added to the list for this national park and Vietnam's flora.

Clearly, the results show that the VPS in the BMNP is relatively diverse with 6 plant phylums. In which, Mangnoliophyta phylum dominated with 1,663 species (89.03\%) and 157 families (81.77\%). Meanwhile, although phylums of Equisetophyta and Psilotophyta contributed only 1 family, 1 species of each, the species significantly provide conservation and scientific values, including Psilotum nudum (L.) P. Beauv and Equisetum ramosissimum Desf. subsp. debile
(Roxb. ex Vaucher) Hauke. Notably, Polypodiophyta phylum is ranked 2nd in diversity with 24 families and 170 species (Table 2). Families of Polypodiaceae, Thelypteridaceae, and Dennstaedtiaceae account for the highest number of species with $13.53 \%, 10.59 \%$ and 8.82 respectively.

To assess the diversity of the VPS composition in the BMNP, the research designed a comparison with the national flora (Table 3). Specifically, the number of flora families in the park is diverse, reaching 192 families. Compared with the 308 found in the whole country, it accounts for 62.34\%. Although contributing only 1 family, there are 2 phylums with 100\% including Psilotophyta and Equisetophyta. Moreover, Polypodiophyta and Pinophyta phylums also showed a high percentage of families with $82.76 \%$ and $77.78 \%$ respectively. However, the data represents a low species diversity in this park, with only $13.56 \%$ and most species under 50\% except for Psilotophyta phylum (100\%). 


\section{Table 2. List of families in Polypodiophyta phylum in the BMNP}

\begin{tabular}{|c|c|c|c|}
\hline No. & Polypodiophyta family & Number & $\%$ \\
\hline 1 & Adiantaceae & 8 & 4.71 \\
\hline 2 & Angiopteridaceae & 5 & 2.94 \\
\hline 3 & Aspleniaceae & 6 & 3.53 \\
\hline 4 & Blechnaceae & 3 & 1.76 \\
\hline 5 & Cheiropleuriaceae & 1 & 0.59 \\
\hline 6 & Cyatheaceae & 6 & 3.53 \\
\hline 7 & Davalliaceae & 5 & 2.94 \\
\hline 8 & Dennstaedtiaceae & 15 & 8.82 \\
\hline 9 & Dicksoniaceae & 1 & 0.59 \\
\hline 10 & Dipteridaceae & 5 & 2.94 \\
\hline 11 & Dryopteridaceae & 12 & 7.06 \\
\hline 12 & Gleicheniaceae & 8 & 4.71 \\
\hline 13 & Grammitidaceae & 10 & 5.88 \\
\hline 14 & Hymenophyllaceae & 8 & 4.71 \\
\hline 15 & Lomariopsidaceae & 5 & 2.94 \\
\hline 16 & Oleandraceae & 4 & 2.35 \\
\hline 17 & Osmundaceae & 1 & 0.59 \\
\hline 18 & Plagiogyriaceae & 1 & 0.59 \\
\hline 19 & Polypodiaceae & 23 & 13.53 \\
\hline 20 & Pteridaceae & 11 & 6.47 \\
\hline 21 & Schizaeaceae & 8 & 4.71 \\
\hline 22 & Thelypteridaceae & 18 & 10.59 \\
\hline 23 & Vittariaceae & 4 & 2.35 \\
\hline \multirow[t]{2}{*}{24} & Woodsiaceae & 2 & 1.18 \\
\hline & Total & 170 & 100 \\
\hline
\end{tabular}

Table 3. A comparison of the VPS diversity between the BMNP and whole country

\begin{tabular}{|c|c|c|c|c|c|c|}
\hline \multirow{2}{*}{ Phylums } & \multicolumn{3}{|l|}{ Families } & \multicolumn{3}{|l|}{ Species } \\
\hline & BMNP & Vietnam* & $\%$ & BMNP & Vietnam* & $\%$ \\
\hline Psilotophyta & 1 & 1 & 100.00 & 1 & 1 & 100.00 \\
\hline Lycopodiophyta & 2 & 3 & 66.67 & 17 & 53 & 32.08 \\
\hline Equisetophyta & 1 & 1 & 100.00 & 1 & 2 & 50.00 \\
\hline Polypodiophyta & 24 & 29 & 82.76 & 170 & 691 & 24.60 \\
\hline Pinophyta & 7 & 9 & 77.78 & 22 & 69 & 31.88 \\
\hline Mangnoliophyta & 157 & 265 & 59.25 & 1,663 & 13,000 & 12.79 \\
\hline Total & 192 & 308 & 62.34 & 1,874 & 13,816 & 13.56 \\
\hline
\end{tabular}

* (Source: Thin, 2004)

\subsection{Vascular plant diversity in the BMNP}

\subsubsection{Endemic vascular plants}

As displayed in Table 4, our findings indicate that 199 out of 1,874 vascular species in the BMNP are endemic of Vietnam. Some typical species are Nageia fleuryi, Schefflera pacoensis, Canarium subulatum, Peltophorum dasyrrachis, Diplopanax vietnamensis, Elaeocarpus angustifolius, Rhododendron fortunei, Cryptocarya annamensis and Strychnos dinhensis.
Among them, there are 19 endemic species of the BMNP (Thin, 2004). The first five discovered plant species are named "Bach Ma", including Cissus bachmaensis Gagnep; Elaeocarpus bachmaensis Gagnep; Licuala bachmaensis Henderson, N.K.Ban \& N.Q.Dung; Calamus bachmaensis Henderson, N.K.Ban \& N.Q.Dung; and Glochidion bachmaensis. 


\subsubsection{Endangered, Precious and Rare (EPR) vascular plants}

Currently, three taxonomy systems that are widely used to determine species diversity include the Red List of Vietnam
2007 (RLV), Decree No. 06/2019/ND-CP on Management of EPR Plants and Animals in Vietnam (D06), and the International Union for Conservation of Nature's Red List of Threatened Species 2020 (IUCN). Accordingly, a list of EPR vascular plants in the BMNP follows three of these systems as shown in Table 5.

\section{Table 4. List of endemic vascular plants in the BMNP}

\begin{tabular}{lll} 
No & Species & Local name \\
\hline 1 & Allomorphia inaequata C. Hansen & "Đa hình không bằng" \\
3 & Allomorphia subsessitis Craib & "Đa hình không cuống" \\
4 & Bambusa multiplex (Lour.) Raeusch & "Cỏ lá gừng" \\
5 & Cissus bachmaensis Gagnep. & "Hóp" \\
6 & Glochidion bachmaensis Thin & "Hồ đằng Bạch Mã" \\
7 & Glyptopetalum annamense Tardieu & "Bọt ếch Bạch mã" \\
8 & Mallotus eberhardtii Gagnep. & "Xâm cánh trung bộ" \\
9 & Medinilla assamica (C. B. Clarke) Chen & "Ngoát" \\
10 & Medinilla scortechinii Blume & "Minh điền át-xam" \\
11 & Melastoma eberhardtii Guillaum. & "Minh điền scortechi" \\
12 & Pandanus bipollicaris John & "Muôi ê-béc-hác" \\
13 & Phyllagathis sessilifolia C. Hansen & "Dứa chót ché" \\
14 & Phyllagathis suberalata C. Hansen & "Me nguồn không cuống" \\
15 & Quercus auricoma A. Camus & "Me nguồn cánh" \\
16 & Reevesia gagnepainiana Tardieu & "Sồi tóc vàng" \\
17 & Rhododendron fortunei Lindl. & "Trường hùng ga-nhép-panh" \\
18 & Tarenna annamensis Pit. & "Đỗ quyên vân cẩm" \\
19 & Wikstromia poilanei Leandri & "Trèn trung bộ" \\
\hline
\end{tabular}

Table 5. List of the EPR vascular plants in BMNP

\begin{tabular}{|c|c|c|c|c|c|}
\hline \multirow[t]{2}{*}{ Catalogues } & \multirow[t]{2}{*}{ Phylums } & \multicolumn{2}{|l|}{ Families } & \multicolumn{2}{|l|}{ Species } \\
\hline & & Number & $\%$ & Number & $\%$ \\
\hline \multirow{5}{*}{ RLV, 2007} & Lycopodiophyta & 1 & 2.50 & 1 & 1.17 \\
\hline & Polypodiophyta & 1 & 2.50 & 1 & 1.17 \\
\hline & Pinophyta & 4 & 10.00 & 5 & 5.32 \\
\hline & Mangnoliophyta & 34 & 85.00 & 87 & 92.54 \\
\hline & Total & 40 & 100 & 94 & 100 \\
\hline \multirow[t]{3}{*}{ D06, 2019} & Pinophyta & 4 & 40.00 & 9 & 33.33 \\
\hline & Mangnoliophyta & 6 & 60.00 & 18 & 66.67 \\
\hline & Total & 10 & 100 & 27 & 100 \\
\hline \multirow[t]{4}{*}{ IUCN, 2020} & Polypodiophyta & 13 & 14.13 & 15 & 5.68 \\
\hline & Pinophyta & 7 & 7.60 & 28 & 10.60 \\
\hline & Mangnoliophyta & 72 & 78.27 & 221 & 83.72 \\
\hline & Total & 92 & 100 & 264 & 100 \\
\hline
\end{tabular}

Regarding the RLV list, the composition of rare and precious phytoplankton species in the BMNP includes 94 species, 40 families, 4 phylums; the Magnoliophyta phylum is the most diverse accounting for $92.54 \%$ (87/94) species and $85.0 \%$ (34/40) families; this is followed by the phylum of Pinophyta accounting for $5.32 \%$ (5/94) species and 10.0\% (4/40) families. Lycopodiophyta and Polypodiophyta phylums contribute only 1 species and 1 family each. According to the D06, 27 species, 10 families, 2 divisions: Magnoliophyta (6 families and 18 species), and Pinophyta (4 families and 9 species) are identified as EPR vascular plants in the BMNP. Meanwhile, the list of the IUCN indicates that there are 264 species, 92 species, and 3 phylums, found in the BMNP. Similarly, Magnoliophyta phylum is the most diverse with 221 
species (83.72\%) and 72 families (78.27\%), followed by the Pinophyta (28 species and 7 families) and Polypodiophyta phylums (15 species and 13 families).

It is worth noting that different catalogs have different indicators/sub-indicators for identifying different EPR species (Table 6). Accordingly, while the IUCN (2020) and the RLV (2007) divided EPR species into 3 levels, called critically endangered species (CR), endangered species (EN), and vulnerable species (VU); the classification system followed by D06 degree (2019) lists the EPR plant species into 2 levels including IA and IIA corresponding to forbidden and restricted plant species respectively. Accordingly, 55 species are belonging to the IUCN, in which 9 CR species, 15 EN species, and $31 \mathrm{VU}$ species.

According to the rankings of the RLV (2007), 6 species of CR (accounting for $13.64 \%$ compared with the whole country), 36 species of EN (20\%), and 52 species of VU (26\%) were listed in this park. Finally, based on the list of endangered and rare flora and fauna in D06 degree (2019), the composition of plant species in BMNP has 27 species including 5 species of IA (5/15 compared with the whole country) and 22 species belonging to IIA (22/37).

Table 6. List of the EPR vascular plants according to each Red List Category

\begin{tabular}{|c|c|c|c|c|c|c|}
\hline Catalogues & $\begin{array}{l}\text { Red List } \\
\text { Category }\end{array}$ & Lycopodiophyta & Polypodiophyta & Pinophyta & Mangnoliophyta & Total \\
\hline \multirow{3}{*}{ IUCN 2020} & $C R$ & - & - & - & 9 & 9 \\
\hline & EN & - & - & 2 & 13 & 15 \\
\hline & VU & - & 1 & 8 & 21 & 31 \\
\hline \multirow[t]{2}{*}{ Total } & & - & 1 & 10 & 43 & 55 \\
\hline & $C R$ & - & - & 1 & 5 & 6 \\
\hline \multirow[t]{2}{*}{ RLV, 2007} & EN & - & - & 1 & 35 & 36 \\
\hline & VU & 1 & 1 & 4 & 46 & 52 \\
\hline \multicolumn{2}{|l|}{ Total } & 1 & 1 & 6 & 86 & 94 \\
\hline \multirow{2}{*}{ D06, 2019} & $\mathrm{IA}$ & - & - & 1 & 4 & 5 \\
\hline & $\| A$ & - & - & 8 & 14 & 22 \\
\hline Total & & - & - & 9 & 18 & 27 \\
\hline
\end{tabular}

\subsection{Distribution of vascular plant species}

According to the UNESCO's classification of 1973, the vegetation cover of the BMNP belongs to the tropical evergreen forest ecosystem, a mixed rain forest ecosystem with complex plant species composition but without dominant species. Most plant species have only a few individuals in the population. Accordingly, the distribution of vascular plant species found are of 2 types:

Type 1: Rain-loving tropical evergreen forest of the low belt below 900m (Figure 2). This type includes 4 types of richness forest, medium forest, poor forest, and restored young forest with 4 main communities. (1) tropical evergreen forests prefer rain with broadleaf trees that are less affected, dominant species such as Parashorea stellata, Scaphium macropodium, Pometia pinnata; (2) tropical evergreen forest prefers broad-leaved and secondary trees that are strongly affected, with dominant species such as Ormosia dasycarpa, Macaranga denticulate, Cratoxylon formosum; (3) secondary scrub, evergreen broadleaf, dominant species such as Rhodomyrtus tomentosa, Cratoxylon formosum, Mallotus paniculatus; and (4) secondary tropical grassland, dominant species such as Saccharum spontaneum, Imperata cylindrical.

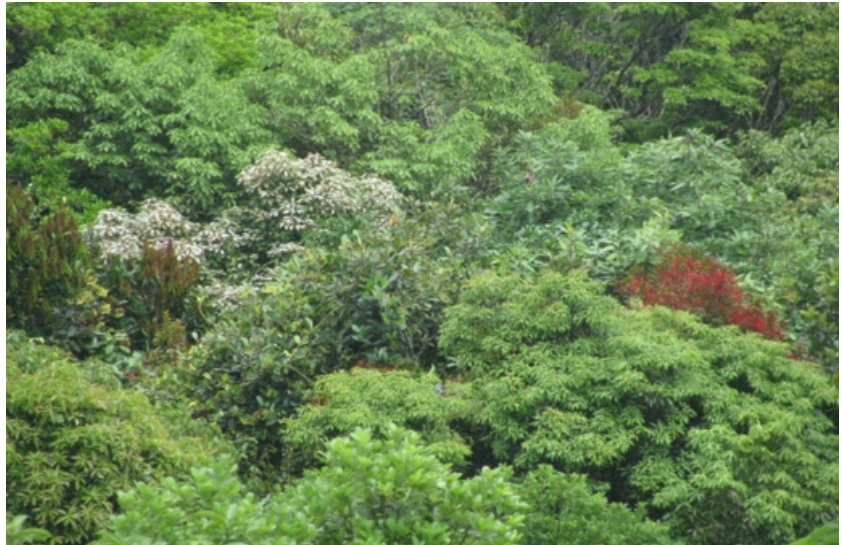

Figure 2. Vascular plants distribution type 1 (bellow 900m). Source: Keo et al., 2016

Type 2: Monsoon tropical evergreen forest with low mountain belt over $900 \mathrm{~m}$ (Figure 3). This type is represented by 3 communities of poor forest and restored young forest including: (1) the monsoon tropical evergreen forest (9001292m), which has little impact with dominant species like Dacrydium elatum, Lithocarpus fenestratus, Michelia foveolata; (2) monsoon tropical evergreen forest (1292-1400m), is strongly affected with dominant species such as Phoebe tavoyana, Saurauia roxburghii and Acer tonkinensis; (3) rainforest evergreen monsoon belt (1400 m - 1712m) with 
some dominant plants such as Pinus dalatensis Ferre, Cunninghamia lanceolata and Rhodoleia champion Hook.

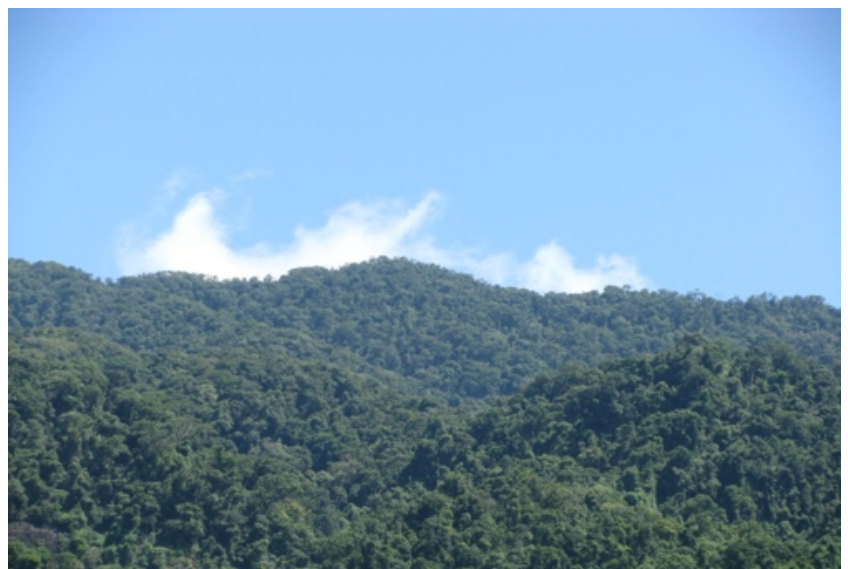

Figure 3. Vascular plants distribution type 2 (over $900 \mathrm{~m}$ ). Source: Keo et al., 2016

\section{Conclusion}

In summary, the BMNP is one of the highest priority vascular plants area comprising 1,874 species, belonging to 192 families, and 6 phylums. Moreover, this park is an ideal location for biodiversity research and conservation. Many plants are recorded from the park, including those listed in the 2007 Red Data Book of Vietnam and the current IUCN Red List of the Threatened Species. At the same time, each plant elevation has different characteristics of distribution along elevational and temperature gradients. Effective solutions must be therefore taken to protect the sustainable ecological environment, especially endemic and rare species. To achieve this, it is necessary a clear policy and long-term strategies to preserve plant diversity and more specific research.

\section{Acknowledgments}

This research was funded by Hue University under Grant Number DHH2020-17-01. The authors thank the Hue University for their financial support.

\section{References}

[1] An, T.L., Markowski, J., Bartos, M., Thoai, T. Q., Tuan, T. H., \& Rzenca, A. (2018). Tourist and Local Resident Preferences for the Northern Yellow-Cheeked Gibbon (Nomascus annamensis) Conservation Program in the Bach Ma National Park, Central Vietnam. Tropical Conservation Science, 11:1-16. https://doi.org/10.1177/ 1940082918776564

[2] Bach Ma National Park (2020). Retrieved September 18, 2020, from http://bachmapark.com.vn/introduction/ forest-resources_126.html

[3] Ban, N.T, et al., (2007). The Vietnam Red List. Hanoi: Science and Technics Publishing House.

[4] Bruner AG, Gullison RE, Rice RE, Fonseca GAB. (2001). Effectiveness of parks in protecting tropical biodiversity. Science. 291: 125-128. https://www.doi.org/10.1126/ science.291.5501.125

[5] Dai, D.N, and Huong, L.T., (2009). Research and assessment of plant diversity (species composition, use value, rare genetic resources, geographic factors, life form spectrum) in Bach Ma National Park. Retrieved from http://www.cesti.gov.vn/chi-tiet/4681/khcn-trongnuoc/nghien-cuu-tinh-da-dang-he-thuc-vat-bac-caoco-mach-o-vuon-quoc-gia-bach-ma

[6] Dan, L.V, et al., (2014). Establishment survey of contents list of species fish in the expansion area of Bach Ma National Park. 4: 210-217.

[7] Fois, M., Podda, L., Médail, F., \& Bacchetta, G. (2020). Endemic and alien vascular plant diversity in the small Mediterranean islands of Sardinia: Drivers and implications for their conservation. Biological Conservation, 244, 108519. https://doi.org/10.1016/ j.biocon.2020.108519

[8] Ho, P. H (1991). Vietnamese Flora. Issues 1. Tre Publishing House, Hanoi.

[9] Ho, P. H (1992). Vietnamese Flora. Issues 2. Tre Publishing House, Hanoi.

[10] Ho, P. H (1993). Vietnamese Flora. Issues 3. Tre Publishing House, Hanoi.

[11] IUCN (2020). Planned Red List Updates. Retrieved September 20, 2020, from https://www.iucnredlist.org/ assessment/updates

[12] Iwanaga, S., Yokoyama, S., Duong, D. T., \& Minh, N. Van. (2019). Policy effects for forest conservation and local livelihood improvements in Vietnam: a case study on Bach Ma National Park. Journal of Forest Research, 24(5): 267-274. https://doi.org/10.1080/13416979. 2019.1655129

[13] Keo, H.V, An, T.T, Thang, N.V (2016). Flora in Bach Ma National Park. Hue University Publishing House, Thua Thien Hue, Vietnam. ISBN 978-604-912-601-7.

[14] Nakano, S., Yahara, T., \& Nakashizuka, T. (ed.) (2012). The Biodiversity Observation Network in the Asia-Pacific Region: Toward Further Development of Monitoring. Springer Japan. https://doi.org/10.1007/978-4-43154032-8

[15] Phu, V.V, (1999). Biodiversity in Bach Ma National Park. Journal of Science and Technology. Vietnam National Institute of Occupational Safety and Health (VN NIOSH). 
23-24p.

[16] Quang, H.X, Thao H.N, Tuan H.A, (2007). Amphibians and reptiles supplementing the North Central region are recorded in Bach Ma National Park. Science and Technics Publishing House, Hanoi.

[17] Thin, N.N (2004). Tropical Forest Ecosystem. Vietnam National University Press, Hanoi.

[18] UNESCO Paris, (1973). International classification and mapping of vegetation. Published by the United Nations Educational, Scientific and Cultural Organization. ISBN 92-3-001046-4 LC No. 72-96442, 102, 13-37.

[19] Vietnamese Government. (2019). Decree No. 06/2019 ND-CP on management of endangered, precious and rare forest plants and animals, and the implementation of the Convention on international trade in endangered species of wild fauna and flora level. 